University of Nebraska - Lincoln

DigitalCommons@University of Nebraska - Lincoln

Faculty Papers and Publications in Animal

Science

Animal Science Department

March 1985

\title{
REDUCED NOCTURNAL TEMPERATURES FOR EARLY WEANED PIGS
}

\author{
M. C. Brumm \\ University of Nebraska Northeast Station, Concord, mbrumm@hickorytech.net \\ D. P. Shelton \\ University of Nebraska Northeast Station, Concord \\ R. K. Johnson \\ University of Nebraska-Lincoln, rjohnson5@unl.edu
}

Follow this and additional works at: https://digitalcommons.unl.edu/animalscifacpub

Part of the Animal Sciences Commons

Brumm, M. C.; Shelton, D. P.; and Johnson, R. K., "REDUCED NOCTURNAL TEMPERATURES FOR EARLY WEANED PIGS" (1985). Faculty Papers and Publications in Animal Science. 39.

https://digitalcommons.unl.edu/animalscifacpub/39

This Article is brought to you for free and open access by the Animal Science Department at DigitalCommons@University of Nebraska - Lincoln. It has been accepted for inclusion in Faculty Papers and Publications in Animal Science by an authorized administrator of DigitalCommons@University of Nebraska - Lincoln. 


\title{
REDUCED NOCTURNAL TEMPERATURES FOR EARLY WEANED PIGS ${ }^{1,2,3}$
}

\author{
M. C. Brumm ${ }^{4}$, D. P. Shelton ${ }^{5}$ and R. K. Johnson ${ }^{4}$ \\ University of Nebraska Northeast Station, Concord 68728
}

\begin{abstract}
Three experiments of 5 wk duration were conducted to evaluate the effect of reduced nocturnal temperatures (RNT) on weaned pig performance. Treatments were 1) a control regimen (CR) of $30 \mathrm{C}$ constant air temperature lowered $2 \mathrm{C} / \mathrm{wk}$ and 2) a regimen where the temperature from 1900 to $0700 \mathrm{~h}$ was lowered to $25 \mathrm{C}$ for three nights followed by $20 \mathrm{C}$ for four nights during the first week and then lowered $1 \mathrm{C} /$ wk thereafter (RNT). Weaned pigs averaging $23 \pm 2 \mathrm{~d}$ of age at the start of the experiments gained faster $(P<.01)$ in the RNT treatment vs the CR treatment in Exp. 1,2 and 3, respectively (.32 vs $.28 ; .39 \mathrm{vs} .37 ; .35 \mathrm{vs} .34 \mathrm{~kg} / \mathrm{d}$ ). The improvement in gain was accompanied by an increase $(\mathrm{P}<.005)$ in feed intake for the same period $(.48$ vs $.44 ; .61$ vs $.55 ; .58$ vs $.54 \mathrm{~kg} / \mathrm{d})$. There was no difference in feed conversion. Weaned pigs that were 1.9 to $2.3 \mathrm{~kg}$ lighter initially gained slower $(\mathrm{P}<.0005)$ compared with their heavier contemporaries (.27 vs $.33 ; .33$ vs .43 and $.31 \mathrm{vs} .33 \mathrm{~kg} / \mathrm{d}$ ) in Exp. 1,2 and 3, respectively. This reduced gain was accompanied by a reduced $(P<.0005)$ feed intake $(.40$ vs $.51 ; .50$ vs $.66 ; .50$ vs $.62 \mathrm{~kg} / \mathrm{d}$ ). There was no interaction of initial weight and temperature regimen.
\end{abstract}

(Key Words: Temperatures, Pigs, Early Weaning.)

\section{Introduction}

The current air temperature recommendation for pigs weaned at 3 to 4 wk of age is $29 \mathrm{C}$ at pig level at weaning, with temperature reductions of approximately $2 \mathrm{C} / \mathrm{wk}$ to a minimum of $21 \mathrm{C}$ at $8 \mathrm{wk}$ of age (MWPS, 1983). LeDividich (1981) concluded that 3 -wk-old, weaned pigs reared in groups in wire cages require environmental temperatures of approximately $28 \mathrm{C}$ for $12 \mathrm{~d}$ after weaning, with a $2 \mathrm{C}$ drop each following week. Further, continuous temperature fluctuations of $\pm 4 \mathrm{C}$ hourly were found to affect adversely the overall performance of piglets, especially during the first week after weaning.

McCracken and Caldwell (1980) reported that pigs weaned at $10 \mathrm{~d}$ of age had a marked diurnal pattern of heat production with the lowest heat production occurring during

\footnotetext{
${ }^{1}$ Journal paper no. 7545 , Univ. of Nebraska Agr. Exp. Sta.

${ }^{2}$ The authors acknowledge the assistance of Mr. Dennis Forsberg with animal care and Mr. Dave Pankaskie with data collection and analysis.

${ }^{3}$ Funded in part by a grant from the Nebraska Pork Producers Association, Lincoln, NE 68583.

${ }^{4}$ Dept. of Anim. Sci.

${ }^{5}$ Dept. of Agr. Eng.

Received July 30, 1984.

Accepted May 16, 1985.
}

nighttime hours. Balsbaugh and Curtis (1979) reported that weaned pigs demonstrated a preference for cooler surroundings at night. Curtis and Morris (1982) reported no significant differences in daily gain or gain to feed ratio for 4-wk-old, weaned pigs housed in a nursery room maintained at a constant $26.7 \mathrm{C}$ and those housed in a room where the air temperature fluctuated between an average daily maximum of $26.3 \mathrm{C}$ and an average daily minimum of $15.1 \mathrm{C}$.

The objective of this research was to determine the effect of reduced nocturnal temperatures on weaned pig performance.

\section{Materials and Methods}

Three experiments of 5 wk duration were conducted at the University of Nebraska's Northeast Station (table 1). Three hundred eighty-four crossbred feeder pigs averaging $23 \pm 2 \mathrm{~d}$ of age at the start of the experiments were utilized.

Facility Description. A two-room nursery was used in which each room had individual heating, ventilation, energy and manure handling systems. Each room contained four flat-deck pens with woven wire flooring and open mesh partitions. Each pen was divided into two $1.2 \times 1.2 \mathrm{~m}$ pens for a total of eight pens/room. Each $1.44 \mathrm{~m}^{2}$ pen housed eight pigs $\left(.18 \mathrm{~m}^{2} / \mathrm{pig}\right)$ with one nipple drinker 
TABLE 1. INCLUSIVE DATES FOR EXPERIMENTS

\begin{tabular}{ll}
\hline Experiment & \multicolumn{1}{c}{ Dates } \\
\hline Uniformity trial & September 11 to October 16, 1980 \\
Reduced nocturnal \\
temperatures & October 15 to November 19,1982 \\
Exp. 1 & October 31 to December 5, 1983 \\
Exp. 2 & February 1 to March 7, 1984 \\
Exp. 3 & \\
\hline
\end{tabular}

and one five-hole self-feeder occupying .03 $\mathrm{m}^{2}$ of pen space.

A low-volume fan in each room continuously exhausted air $(97$ liters $/ \mathrm{s}$ at $3 \mathrm{~mm}$ $\mathrm{H}_{2} \mathrm{O}$ static pressure) from the manure pit for minimum ventilation. Although relative humidity was not measured, the ventilation system was designed to maintain relative humidity below $70 \%$ at the temperatures employed in these trials. Supplemental heat was provided by identical propane-fired furnaces in each room. Further facility details and energy use calculations have been described by Shelton and Brumm (1984).

Pigs. Within $2 \mathrm{~h}$ of removal from the sow, locally purchased pigs were weighed, eartagged and sexed. They were transported by covered truck approximately $32 \mathrm{~km}$ and were allotted by sex and weight-outcome groups to the experimental treatments. Pigs were allotted to heavy and light initial weight outcome groups to reduce variation in weight within pens. A pelletted commercial pig starter containing $18 \%$ crude protein, $1.15 \%$ lysine, $200 \mathrm{mg} / \mathrm{kg}$ furazolidone, $100 \mathrm{mg} / \mathrm{kg}$ oxytetracycline hydrochloride and $100 \mathrm{mg} / \mathrm{kg}$ arsanilic acid was fed for the duration of the experiments. Pigs were weighed weekly and feed efficiency was determined from weekly feed consumption records.

Air Temperature. Two air-temperature management regimens (target temperatures) were employed. The furnace thermostat in the control treatment room (CR) was set to maintain a dry-bulb temperature of $30 \mathrm{C}$ during the first week of each experiment. The control room temperature was then decreased $2 \mathrm{C} / \mathrm{wk}$ thereafter. In the treatment room with reduced nocturnal temperatures (RNT), room air temperatures were to be maintained the same as in the control room for $12 \mathrm{~h} / \mathrm{d}(0700$ to $1900 \mathrm{~h})$. During night time hours (1900 to 0700), thermostat set- tings or air temperatures were reduced to $25 \mathrm{C}$ for the first three nights, then to $20 \mathrm{C}$ for the next four nights. Nighttime air temperatures were then further reduced by $1 \mathrm{C} / \mathrm{wk}$ for the subsequent 4 wk of each experiment. Treatments were alternated between rooms.

Temperature was regulated by using dual thermostats controlled by a switching timeclock. All thermostats were equipped with capillary tubes having sensing bulbs located near the pen area at animal level.

Air temperatures were measured and recorded hourly using copper-constantan thermocouples and an automatic data logger. One thermocouple (eight/room) was placed approximately $12 \mathrm{~cm}$ above the pen floor in a corner of each animal pen at the center of the main pen. Protection from the animals was provided by placing each thermocouple inside a $3-\mathrm{cm}$ diameter perforated PVC pipe.

Air velocities in the center of the animal pen area and at various points between adjacent pens were measured in three planes, using a hand-held, hot-tip air velocity meter. These readings were taken before initiation of the experiment when the low-volume winter ventilation and furnace fans were operating, but when no pigs were in the pens. Air velocities were generally found to be less than $.05 \mathrm{~m} / \mathrm{s}$, which is generally perceived as still-air by the weaned pig (Curtis, 1981).

Uniformity Trial. Before the initiation of these experiments, a uniformity experiment was conducted to determine if performance differed between rooms. Both rooms were managed according to the $\mathrm{CR}$ regimen described earlier. Within each room, 64 pigs were housed in four $1.2 \times 2.4 \mathrm{~m}\left(.18 \mathrm{~m}^{2} /\right.$ pig), flat-deck pens with woven wire flooring, open mesh partitions, two five-hole feeders and one nipple drinker.

Statistical Analysis. Statistical analyses were performed using the general linear model procedure as outlined by SAS (1979). The pen of pigs was considered to be the experimental unit. Sources of variation and degrees of freedom for both the uniformity experiment and the reduced nocturnal temperature experiments are given in table 2 . Pens within room was used to test for a room effect in the uniformity trial, while all main effects and interactions were tested using the error term indicated for the reduced nocturnal trials. 
TABLE 2. SOURCES OF VARIATION IN THE ANALYSIS OF VARIANCE

\begin{tabular}{|c|c|c|}
\hline Experiment & Source & df \\
\hline \multicolumn{3}{|c|}{ Uniformity trial } \\
\hline & Pens/room & 6 \\
\hline & \multicolumn{2}{|l|}{ Total } \\
\hline \multicolumn{3}{|c|}{ Reduced nocturnal trials } \\
\hline & \multirow{2}{*}{$\begin{array}{l}\text { Experiment (E) } \\
\text { Temperature (T) }\end{array}$} & 2 \\
\hline & & 1 \\
\hline & Weight (W) & 1 \\
\hline & $\mathrm{E} \times \mathrm{T}$ & 2 \\
\hline & $\mathrm{E} \times \mathbf{W}$ & 2 \\
\hline & $T \times W$ & 1 \\
\hline & $E \times T \times W$ & 2 \\
\hline & \multirow[t]{2}{*}{ Error } & 36 \\
\hline & & $\overline{47}$ \\
\hline
\end{tabular}

\section{Results}

The results of the uniformity experiment are presented in table 3 . There was no effect ( $P>.25$ ) of room on any of the performance traits measured. Hence, in the analysis of the data for the other experiment pens within rooms were considered to be the experimental units.

There was an interaction $(\mathrm{P}<.001)$ between initial weight group and temperature regimen for average daily gain (ADG) for wk 0 to 1 . The heavy pigs tended to gain less on the RNT treatment in Exp. 1, 2 and 3 (.19 vs .21; .09 vs $.25 ; .12 \mathrm{vs} .12 \mathrm{~kg} / \mathrm{d}$ ), while the response of the lighter-weight pigs was more variable (.22 vs $.15 ; .11$ vs $.16 ; .09$ vs $.03 \mathrm{~kg} / \mathrm{d}$ ).

Because none of the other interactions between initial weight and temperature was significant, performance data are reported separately for the main effects of temperature (table 4) and initial weight (table 5). Because of

TABLE 3. UNIFORMITY EXPERIMENT OF PIG PERFORMANCE IN FACILITY

\begin{tabular}{lrcr}
\hline & \multicolumn{3}{c}{ Room ${ }^{\mathrm{ab}}$} \\
\cline { 2 - 4 } Item & 1 & 2 & $\mathrm{SE}^{\mathrm{c}}$ \\
\hline ADG, kg & .37 & .38 & .01 \\
ADF, kg & .62 & .63 & .01 \\
Feed/gain & 1.69 & 1.67 & .03 \\
\hline
\end{tabular}

${ }^{\mathrm{a}}$ Sixty-four pigs/room.

$\mathrm{b}_{\text {Initial weight, } 6.5 \mathrm{~kg} \text {. }}$

${ }^{\mathrm{c}} \mathrm{Standard}$ error of the mean. interactions $(\mathrm{P}<.05)$ between experiment and temperature and experiment and weight, the data were not pooled across experiments. In most instances, these interactions reflect differences in magnitude of response between experiments.

There was an improvement in overall $A D G$ $(\mathrm{P}<.01)$ and average daily feed $(\mathrm{ADF} ; \mathrm{P}<.005)$ for RNT pigs in all experiments (table 4). In addition, ADF was increased for RNT pigs for all time periods. However, this increase in feed intake did not always result in improved gain. There was an improvement in gain for the second week $(\mathrm{P}<.005)$, the fifth week $(\mathrm{P}<.01)$ and overall $(\mathrm{P}<.01)$ for the RNT pigs.

There was no difference in feed conversion for the different temperature regimens for the time periods evaluated. Hence, the improved gain for the RNT treatment for wk 0 to 5 is probably a reflection of an increased feed intake for the same period.

Figure 1 is a plot of the mean hourly temperatures by week pooled across all experiments. While a definite diurnal fluctuation was achieved for the RNT treatment, the rate of cool-down was dependent on outside air temperature, pig mass and building mass. By the fifth week of each trial, the target temperature of $16 \mathrm{C}$ was seldom achieved, and then only for 1 or $2 \mathrm{~h}$ just before 0700 h. The mean weekly air temperatures with standard deviations recorded at pig height are given in table 6. A standard deviation is not reported for the RNT means because of the variation that was planned for this treatment. The decreased difference in mean temperatures for the CR and RNT treatments as the trials progressed is primarily due to the fact that the daytime temperature was lowered $2 \mathrm{C} / \mathrm{wk}$, while the nocturnal temperature was lowered only $1 \mathrm{C} / \mathrm{wk}$.

Total energy (propane and electricity cost) used to maintain the experimental temperatures was reduced $28.0,29.7$ and $32.4 \%$ for the RNT vs CR environments in Exp. 1, 2 and 3, respectively.

\section{Discussion}

Results of this study support Balsbaugh and Curtis (1979) and Curtis and Morris (1982), who reported that weaned pigs chose cooler air temperatures at night and continued to gain at rates equal to pigs with no temperature 
choice. Baldwin and Ingram (1968) demonstrated that 8-wk-old pigs that had been trained to operate a set of infrared heaters preferred to huddle together during the night even though ambient temperatures were lower.

These results support the theory that the temperature needs of the weaned pig are diurnal in nature. The apparent preference by the weaned pig for a diurnal temperature fluctuation (Balsbaugh and Curtis, 1979; Curtis and Morris, 1982), and the improved gain reported in the study reported herein, may be related to the pig's diurnal pattern of heat production and heat loss.

Heat loss from groups of pigs has been shown to exhibit a 24-h cycle, with a maximum rate in late afternoon and a minimum rate in early morning (Mount et al., 1961). For pigs weaned at $10 \mathrm{~d}$ into a constant temperature environment, McCracken and Caldwell (1980) reported a marked pattern of diurnal heat production, with the lowest values occurring between 2400 and $0800 \mathrm{~h}$. The temperature regimen for the RNT treatment corresponds closely timewise with both of these reports. It also agrees closely with the regimen selected by weaned pigs (Curtis and Morris, 1982). The improvement in gain and feed intake may be indirectly a behavioral response as a result of providing the weaned pig a temperature regimen more closely matched to its patterns of heat production and heat loss than current recommendations (MWPS, 1983).

Morrison et al. (1975) concluded that growth rate and feed conversion for 37 - to $60-\mathrm{kg}$ pigs were not affected by a $10 \mathrm{C}$ range in diurnal air temperature cycle compared with a constant temperature that was equal

TABLE 4. EFFECT OF REDUCED NOCTURNAL TEMPERATURES ON WEANED PIG PERFORMANCE

\begin{tabular}{|c|c|c|c|c|c|c|c|c|}
\hline \multirow[b]{3}{*}{ Item } & \multirow[b]{3}{*}{ Period, wk } & \multicolumn{6}{|c|}{ Trial $^{\mathrm{a}}$} & \multirow[b]{3}{*}{$\mathrm{SE}^{\mathrm{C}}$} \\
\hline & & \multicolumn{2}{|c|}{1} & \multicolumn{2}{|c|}{2} & \multicolumn{2}{|c|}{3} & \\
\hline & & $\mathrm{CR}^{\mathrm{b}}$ & $\mathrm{RNT}^{\mathrm{b}}$ & CR & RNT & CR & RNT & \\
\hline$A D G^{d}, k g$ & $\begin{array}{l}0 \text { to } 1^{\mathrm{e}} \\
1 \text { to } 2^{\mathrm{fg}} \\
2 \text { to } 3 \\
3 \text { to } 4 \\
4 \text { to } 5^{\mathrm{h}} \\
0 \text { to } 5^{\mathrm{h}}\end{array}$ & $\begin{array}{l}.18 \\
.24 \\
.22 \\
.38 \\
.38 \\
.28\end{array}$ & $\begin{array}{l}.20 \\
.23 \\
.25 \\
.42 \\
.49 \\
.32\end{array}$ & $\begin{array}{l}.20 \\
.23 \\
.39 \\
.51 \\
.51 \\
.37\end{array}$ & $\begin{array}{l}.10 \\
.29 \\
.44 \\
.51 \\
.61 \\
.39\end{array}$ & $\begin{array}{l}.08 \\
.16 \\
.33 \\
.60 \\
.55 \\
.34\end{array}$ & $\begin{array}{l}.10 \\
.24 \\
.26 \\
.58 \\
.55 \\
.35\end{array}$ & $\begin{array}{l}.01 \\
.02 \\
.03 \\
.03 \\
.03 \\
.01\end{array}$ \\
\hline $\mathrm{ADF}, \mathrm{kg}$ & $\begin{array}{l}0 \text { to } 1^{g h} \\
1 \text { to } 2^{\mathrm{fi}} \\
2 \text { to } 3 \\
3 \text { to } 4^{\mathrm{f}} \\
4 \text { to } 5^{\mathrm{gh}} \\
0 \text { to } 5^{\mathrm{f}}\end{array}$ & $\begin{array}{l}.20 \\
.34 \\
.43 \\
.55 \\
.66 \\
.44\end{array}$ & $\begin{array}{l}.23 \\
.35 \\
.47 \\
.62 \\
.69 \\
.48\end{array}$ & $\begin{array}{l}.23 \\
.36 \\
.65 \\
.73 \\
.97 \\
.55\end{array}$ & $\begin{array}{r}.24 \\
.36 \\
.63 \\
.81 \\
1.04 \\
.61\end{array}$ & $\begin{array}{l}.17 \\
.26 \\
.53 \\
.83 \\
.92 \\
.54\end{array}$ & $\begin{array}{l}.20 \\
.33 \\
.54 \\
.84 \\
.97 \\
.58\end{array}$ & $\begin{array}{l}.01 \\
.01 \\
.02 \\
.02 \\
.02 \\
.02\end{array}$ \\
\hline Feed/gain & $\begin{array}{l}0 \text { to } 1 \\
1 \text { to } 2 \mathrm{~g} \\
2 \text { to } 3 \\
3 \text { to } 4 \\
4 \text { to } 5 \\
0 \text { to } 5\end{array}$ & $\begin{array}{l}1.11 \\
1.45 \\
2.88 \\
1.47 \\
2.04 \\
1.55\end{array}$ & $\begin{array}{l}1.22 \\
1.58 \\
1.94 \\
1.52 \\
1.47 \\
1.50\end{array}$ & $\begin{array}{l}1.16 \\
1.63 \\
1.76 \\
1.50 \\
1.97 \\
1.51\end{array}$ & $\begin{array}{l}3.83 \\
1.28 \\
1.46 \\
1.63 \\
1.72 \\
1.58\end{array}$ & $\begin{array}{l}4.99 \\
2.80 \\
1.67 \\
1.38 \\
1.69 \\
1.59\end{array}$ & $\begin{array}{l}2.15 \\
1.48 \\
2.11 \\
1.45 \\
1.76 \\
1.66\end{array}$ & $\begin{array}{r}1.12 \\
.14 \\
.43 \\
.09 \\
.13 \\
.04\end{array}$ \\
\hline
\end{tabular}

\footnotetext{
${ }^{a}$ Sixty-four pigs - temperature ${ }^{-1}$ experiment ${ }^{-1} \cdot$.

${ }^{b} \mathrm{CR}=$ control; $\mathrm{RNT}=$ reduced nocturnal temperature.

$\mathrm{C}_{\text {Standard error of the mean. }}$

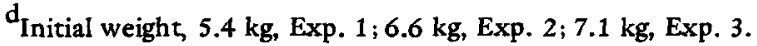

Experiment $X$ temperature $(P<.0001)$.

$f_{\text {Temperature effect }}(P<.005)$.

$\mathrm{g}_{\text {Experiment }} \mathrm{X}$ temperature $(\mathrm{P}<.05)$.

$h_{\text {Temperature effect }}(P<.01)$.

${ }^{i}$ Experiment $X$ temperature $(P<.01)$.
} 
to the mean of the cycle when the mean temperatures were optimal. Curtis (1981) concluded that growing pigs can tolerate a daily range in environmental temperature as long as the mean daily temperature is within an optimal range.

The night temperature achieved in these trials and the overall average temperatures (table 6) were lower than the lower critical temperature reported by Noblet and LeDividich (1982) for pigs of similar size as those used in these experiments. They concluded that constant temperatures starting at $28 \mathrm{C}$ and lowered $2 \mathrm{C} / \mathrm{wk}$ were close to the critical temperature pattern of 3 -wkold, weaned pigs. Only during wk 5 was the average temperature for the RNT treatment within this range.

Boon (1981) defined the lower critical temperature as the air temperature below which an animal uses an increased proportion of its food intake to maintain its body temperature. Consequently, feed conversion deteriorates. Using this criterion for estimating lower critical temperature, the pigs on the RNT treatment in these trials were not coldstressed, because there was no difference in feed efficiency (table 3).

This study supports the concept that weaned pigs prefer and perform best with a diurnal temperature fluctuation (Curtis and Morris, 1982). These data do not indicate if the temperature regimen of the RNT treatment is the optimum for maximum pig gain, efficiency and health. The weight $x$ temperature interaction for the first week after weaning also leaves unclear the ideal temperature regimen for a particular weight of weaned pig.

TABLE 5. EFFECT OF INITIAL WEIGHT ON WEANED PIG PERFORMANCE

\begin{tabular}{|c|c|c|c|c|c|c|c|c|}
\hline \multirow[b]{3}{*}{ Item } & \multirow[b]{3}{*}{ Period, wk } & \multicolumn{6}{|c|}{ Trial $^{\mathrm{a}}$} & \multirow[b]{3}{*}{ SE } \\
\hline & & \multicolumn{2}{|c|}{1} & \multicolumn{2}{|c|}{2} & \multicolumn{2}{|c|}{3} & \\
\hline & & $\mathbf{L}^{\mathrm{b}}$ & $\mathbf{H}^{\mathbf{b}}$ & L & $\mathrm{H}$ & $\mathrm{L}$ & $\mathbf{H}$ & \\
\hline Initial weight, $\mathrm{kg}$ & & 4.5 & 6.4 & 5.5 & 7.8 & 6.1 & 8.0 & \\
\hline ADG, kg & $\begin{array}{l}0 \text { to } 1^{\mathrm{de}} \\
1 \text { to } 2^{\mathrm{fg}} \\
2 \text { to } 3_{\mathrm{fh}}^{\mathrm{fh}} \\
3 \text { to } 4^{\mathrm{fh}} \\
4 \text { to } 5^{\mathrm{dg}} \\
0 \text { to } 5^{\mathrm{f}}\end{array}$ & $\begin{array}{l}.18 \\
.18 \\
.23 \\
.32 \\
.43 \\
.27\end{array}$ & $\begin{array}{l}.20 \\
.29 \\
.24 \\
.48 \\
.44 \\
.33\end{array}$ & $\begin{array}{l}.13 \\
.22 \\
.31 \\
.51 \\
.47 \\
.33\end{array}$ & $\begin{array}{l}.17 \\
.29 \\
.51 \\
.51 \\
.65 \\
.43\end{array}$ & $\begin{array}{l}.06 \\
.19 \\
.23 \\
.53 \\
.52 \\
.31\end{array}$ & $\begin{array}{l}.12 \\
.20 \\
.35 \\
.66 \\
.58 \\
.38\end{array}$ & $\begin{array}{r}<.01 \\
.02 \\
.03 \\
.03 \\
.03 \\
.01\end{array}$ \\
\hline $\mathrm{ADF}, \mathrm{kg}$ & $\begin{array}{l}0 \text { to } 1^{f} \\
1 \text { to } 2^{f} \\
2 \text { to } 3^{f h} \\
3 \text { to } 4^{f} \\
4 \text { to } 5^{\mathrm{fh}} \\
0 \text { to } 5^{\mathrm{f}}\end{array}$ & $\begin{array}{l}.18 \\
.29 \\
.41 \\
.52 \\
.61 \\
.40\end{array}$ & $\begin{array}{l}.25 \\
.40 \\
.49 \\
.66 \\
.74 \\
.51\end{array}$ & $\begin{array}{l}.20 \\
.30 \\
.53 \\
.65 \\
.85 \\
.50\end{array}$ & $\begin{array}{r}.27 \\
.42 \\
.76 \\
.89 \\
1.16 \\
.66\end{array}$ & $\begin{array}{l}.16 \\
.26 \\
.46 \\
.73 \\
.88 \\
.50\end{array}$ & $\begin{array}{r}.21 \\
.33 \\
.61 \\
.94 \\
1.02 \\
.62\end{array}$ & $\begin{array}{l}.01 \\
.01 \\
.02 \\
.02 \\
.02 \\
.02\end{array}$ \\
\hline Feed/gain & $\begin{array}{l}0 \text { to } 1 \\
1 \text { to } 2 \\
2 \text { to } 3 \\
3 \text { to } 4^{h} \\
4 \text { to } 5 \\
0 \text { to } 5\end{array}$ & $\begin{array}{r}.99 \\
1.61 \\
1.91 \\
1.63 \\
1.49 \\
1.50\end{array}$ & $\begin{array}{l}1.34 \\
1.42 \\
2.91 \\
1.37 \\
2.03 \\
1.56\end{array}$ & $\begin{array}{l}2.51 \\
1.43 \\
1.71 \\
1.32 \\
1.84 \\
1.53\end{array}$ & $\begin{array}{l}2.47 \\
1.48 \\
1.51 \\
1.82 \\
1.86 \\
1.56\end{array}$ & $\begin{array}{l}5.28 \\
1.58 \\
1.99 \\
1.39 \\
1.70 \\
1.63\end{array}$ & $\begin{array}{l}1.84 \\
1.97 \\
1.78 \\
1.44 \\
1.74 \\
1.62\end{array}$ & $\begin{array}{r}1.12 \\
.14 \\
.43 \\
.09 \\
.13 \\
.04\end{array}$ \\
\hline
\end{tabular}

\footnotetext{
${ }^{a}$ Sixty - four pigs $\cdot$ weight ${ }^{-1} \cdot$ trial $^{-1} \cdot$.

${ }^{b_{L}}=$ lightweight $; H=$ heavyweight.

${ }^{\mathrm{S}} \mathrm{Standard}$ error of the mean.

Weight effect $(P<.005)$.

Weight $X$ temperature effect $(P<.001)$.

$f_{\text {Weight effect }(}(P<.0005)$.

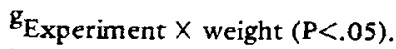

$h_{\text {Experiment }} X$ weight $(P<.01)$.
} 


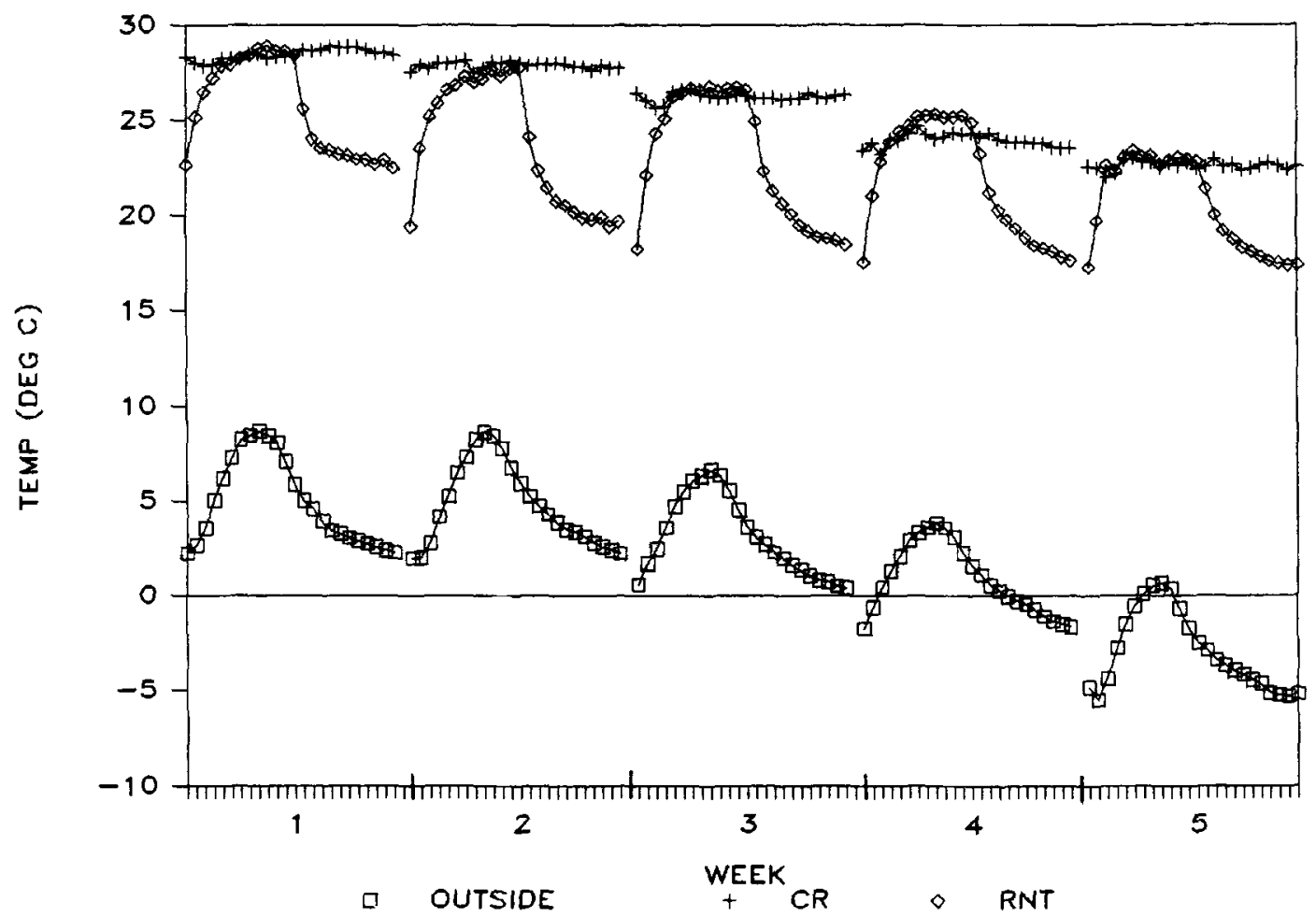

Figure 1. Mean hourly temperature at pig level.

Due to death or severely reduced performance, five pigs $(2.6 \%)$ were removed from test in the RNT regimen over the course of Exp. 1,2 and 3 . One pig $(.5 \%)$ on the $C R$ regimen was removed from test during the same period. These losses occurred primarily in Exp. 3 during an outbreak of diarrhea diagnosed as caused by Salmonella spp. The slightly higher mortality rate in the room with reduced nocturnal temperatures parallels

TABLE 6. MEAN WEEKLY AIR TEMPERATURES AT PIG HEIGHT AVERAGED FOR ALL TRIALS

\begin{tabular}{|c|c|c|}
\hline \multirow[b]{2}{*}{ Week } & \multicolumn{2}{|c|}{ Treatment $^{2}$} \\
\hline & $\mathrm{CR}$ & RNT \\
\hline & 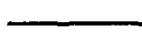 & \\
\hline 1 & $29.1 \pm 3.7$ & 25.8 \\
\hline 2 & $28.2 \pm 1.8$ & 24.1 \\
\hline 3 & $26.2 \pm 1.6$ & 22.8 \\
\hline 4 & $24.4 \pm 1.3$ & 21.6 \\
\hline 5 & $22.3 \pm 1.4$ & 20.5 \\
\hline
\end{tabular}

${ }^{a} \mathrm{CR}=$ control $; \mathrm{RNT}=$ reduced nocturnal temperature. the results reported by Curtis and Morris (1982).

Reduced nighttime temperatures appeared to impose an additional stress, particularly on sick animals, as evidenced by the higher number of animals removed from test. While not tested in these experiments, if sick and(or) severely stressed animals could be placed in a separate pen and provided with supplemental treatment such as a heat lamp, competition with pen-mates would be reduced, and adequate performance might be maintained.

\section{Literature Cited}

Baldwin, B. A. and D. L. Ingram. 1968. Factors influencing behavioural thermoregulation in pigs. Physiol. Behav. 3:409.

Balsbaugh, R. K. and S. E. Curtis. 1979. Operant supplemental heat by pigs in groups: Further observations. J. Anim. Sci. 49 (Suppl. 1):181.

Boon, C. R. 1981. The effect of departures from lower critical temperature on the group postural behavior of pigs. Anim. Prod. 33:71.

Curtis, S. E. 1981. Environmental management in animal agriculture. Animal Environment Services, Mahomet, IL.

Curtis, S. E. and G. L. Morris. 1982. Operant supplemental heat in swine nurseries. In: Livestock 
Environment II. Pub. 382. Amer. Soc. Agr. Eng., St. J oseph, MI.

LeDividich, J. 1981. Effects of environmental temperature on the growth rates of early weaned piglets. Livestock Prod. Sci 8:75.

McCracken, K. J. and B. J. Caldwell. 1980. Studies on diurnal variations of heat production and the effective lower critical temperature of early weaned pigs under commercial conditions of feeding and management. Brit. J. Nutr. 43 : 321.

Morrison, S. R., H. Heitman, Jr. and R. L. Givens. 1975. Effect of diurnal air temperature cycles on growth and food conversion in pigs. Anim. Prod. 20:287

Mount, L. E., M. F. Fuller, K. F. Hosie and D. L.
Ingram. 1961. Climatic studies on pigs. p 23. Rep. Instit. Anim. Physiol. Babraham. 19601961. (as reported in Sainsbury, D. 1979. Pig Housing. Farming Press Ltd., Ipswich, England).

MWPS. 1983. Swine housing and equipment handbook. Midwest Plan Service, Ames, IA.

Noblet, J. and J. LeDividich. 1982. Effect of environmental temperature and feeding level on energy balance traits of early-weaned piglets. Livestock Prod. Sci. 9:619.

SAS. 1979. SAS User's Guide. Statistical Analysis System Institute, Inc., Cary, NC.

Shelton, D. P. and M. C. Brumm. 1984. Response of nursery pigs to reduced nocturnal temperatures. Amer. Soc. Agr. Eng. paper 84-4021. St. Joseph, MI. 